\title{
Model Pengembangan Materi Ajar Pada Pokok Bahasan Morfologi Mikroorganisme Berbasis Scientific Approach Pada Matakuliah Mikrobiologi
}

\author{
Trio Ageng Prayitno \\ Program Studi Pendidikan Biologi IKIP Budi Utomo Malang \\ Jalan Citandui 46 Malang \\ e-mail: trioageng@gmail.com,
}

\begin{abstract}
The learning of microbiology needs the learning materials as a learning resource based on basic competencies to be achieved, so that the learning can be easyly. The purpose of this study is to develop the learning material as microorganism morfology based scientific approach. The learning material developed with Thiagarajan development model consisting of; stage define, design, develop, and disseminate. However, disseminate stage is not implemented. The research data is a validation questionnaire scores the learning material and it is converted in the form of a percentage of the validity criteria. The results showed that the learning material is valid. In conclusion, the learning material as microorganism morfology is valid and viable, so it can be used in the learning of microbiology.
\end{abstract}

Keywords: learning material, scientific approach, development

Tujuan Pendidikan Nasional pada Abad 21 adalah mewujudkan cita-cita bangsa, yakni menjadikan masyarakat bangsa Indonesia yang sejahtera dan bahagia, memiliki kedudukan yang terhormat dan setara dengan bangsa lain dalam dunia global, melalui pembentukan masyarakat yang terdiri dari sumber daya manusia yang berkualitas, yaitu pribadi yang mandiri, berkemauan dan berkemampuan untuk mewujudkan cita-cita bangsa (BNSP, 2010). Tujuan di atas akan tercapai jika pendidikan didukung dengan perkembangan sains dan teknologi. Pendidikan Abad 21 memiliki peran yang sangat penting yakni mampu menjamin peserta didik memiliki keterampilan belajar dan berinovasi, keterampilan menggunakan teknologi dan media informasi, serta mereka dapat bekerja dan bertahan dengan menggunakan keterampilan yang dimilikinya (Murti, 2013). Peran tersebut dapat dengan mudah tercapai bila dalam proses pembelajaran menggunakan pendekatan yang tepat.

Scientific approach adalah sebuah pendekatan yang disarankan pada pendidikan Abad 21. Pendekatan ini dapat dilakukan pada kegiatan teori dan kegiatan praktikum, sehingga mampu menjamin peserta didik dalam menguasai teori, teknologi dan media informasi, serta keterampilan-kerampilan belajar dan berinovasi.
Mikrobiologi adalah salah satu matakuliah yang ada pada Pendidikan Program Studi Pendidikan Biologi IKIP Budi Utomo Malang, yang mana kegiatan pembelajarannya dilakukan dengan kegiatan teori maupun praktikum (SAP Matakuliah Mikrobiologi, 2014).

Hasil observasi oleh peneliti bulan November 2014 menunjukkan bahwa proses perkuliahan mikrobiologi lebih banyak dilakukan dengan kegiatan teori, sedangkan kegiatan praktikum tidak banyak dilakukan karena ketiadaan petunjuk praktikum dan alat serta bahan praktikum. Kegiatan perkuliahan teori dilakukan dengan diskusi dan presentasi. Mahasiswa tidak memiliki buku penunjang materi mikrobiologi dan para mahasiswa lebih suka mendapatkan materi dari blog yang ada di internet, akan tetapi rujuakan itu belum dapat dipertanggungjawabkan kebenarannya.

Materi dan keterampilan dalam kegiatan praktikum mikrobiologi merupakan aspek yang sangat perlu untuk dikuasai oleh para calon guru biologi, sebab materi mikrobiologi juga diajarkan pada jenjang Sekolah Menengah Pertama (SMP) dan Sekolah Menengah Atas (SMA). Melihat pentingnya penguasaan pada materi dan keterampilan praktikum mikrobiologi, namun tidak disertai dengan proses perkuliahan mikrobiologi yang maksimal, maka diperlukan inovasi baru 
yang mampu mendukung proses perkuliahan mikrobiologi dengan baik, yakni salah satunya mengembangkan materi ajar yang didalamnya memuat integrasi antara teori dan kegiatan prakitkum.

Model pengembangan materi ajar pada penelitian ini mengacu pada Thiagarajan Thiagarajan (4D) tahun 1974, yaitu; tahap define, design, develop, dan disseminate (Thiagarajan, 1974). Materi ajar ini juga dikembangkan berdasarkan kebutuhan yang ada pada perkuliahan mikrobiologi di Pendidikan Biologi IKIP Budi Utomountukmenghadapi tantangan pendidikan Abad 21. Hal tersebut dikarenakan dengan penggunaan scientific approach yang mampu menjamin peserta didik untuk mengasosiasikan satu peristiwa dengan yang lain, menanyakan tentang apa yang belum pernah dilakukan, melakukan pengamatan, membuat jejaring untuk mendapatkan informasi, dan terampil melakukan eksperimen (Dyer, et al., 2009). Tujuan dari penelitian ini ialah menghasilkan materi ajar pada pokok bahasan morfologi mikroorganisme berbasis scientif approach yang valid dan layak, sehingga dapat digunakan untuk mendukung perkuliahan mikrobiologi.

\section{METODE}

Materi ajar dikembangkan dengan model pengembangan bahan ajar Thiagarajan, yakni meliputi tahap tahap pendefinisian (define), tahap perencanaan (design), tahap pengembangan (develop), dan tahap penyebarluasan (disseminate). Akan tetapi pada penelian ini tahap penyebarluasan (disseminate) tidak dilaksanakan. Tahapan model pengembangan Thiagarajan (4D) dapat dilihat pada Tabel 1.

Instrumen yang digunakan pada penelitian ini adalah berupa angket validasi oleh ahli materi mikrobiologi, ahli media pembelajaran, pengguna (praktisi lapangan), dan uji coba skala kecil pada mahasiswa yang sedang menempuh matakuliah mikrobiologi. Penjelasan instrumen di atas yakni; (1) angket validasi materi ajar oleh ahli materi mikrobiologi yaitu berupa angket penilaian tentang kebenaran dan kesesuaian konsep serta aplikasi materi mikrobiologi dengan indikator pada kompetensi yang dikembangkan. (2) Angket validasi materi ajar oleh ahli media pembelajaran, yakni berupa angket penilaian tentang desain materi ajar yang dikembangkan oleh peneliti. (3) Angket validasi materi ajar oleh pengguna (praktisi lapangan), yakni penilaian tentang kegunaan materi ajar yang dikembangkan dalam proses perkuliahan mikrobiologi. (4) Angket uji coba skala kecil yaitu angket penilaian tentang keterbacaan dan kelayakan dari materi ajar yang telah dikembangkan.

Data semua hasil validasi oleh para ahli, pengguna (praktisi), dan uji coba skala kecil berupa data kualitatif yang didapatkan dari skor angket. Validasi dilakukan secara kualitatif dan kuantitatif. Data yang digunakan pada penelitian ini ialah data hasil skor yang diberikan pada angket validasi oleh para ahli, pengguna (praktisi), dan uji coba skala kecil. Skor dari angket validasi materi ajar yang dikembangkan menggunakan skala Likert yang terdiri atas 4 kategori pilihan alternatif, yaitu; angkat 4 berarti Baik, angka 3 berarti Cukup baik, angka 2 berarti Kurang baik, dan angka 1 berarti Tidak baik (Sugiyono, 1999).

Data skor yang diperoleh kemudian dilakukan perhitungan rata-rata tiap aspeknya kemudian dirubah dalam bentuk prosentase dengan rumus sebagai berikut ini.

$$
\mathrm{P}=\frac{\sum X}{\sum X 1} 100 \%
$$

\section{Keterangan:}

$$
\begin{array}{ll}
\mathrm{P} & =\text { persentase } \\
\sum \mathrm{X} & =\text { jumlah jawaban seluruh responden } \\
& \text { dalam satu item pertanyaan } \\
\sum \mathrm{X}_{1} & =\text { jumlah jawaban ideal dalam satu item } \\
100 \% & =\text { konstanta }
\end{array}
$$

Kriteria kevalidan data angket penilaian oleh para validator dan hasil uji coba skala kecil ditinjau dari hasil prosentase dapat dilihat pada tabel 2.

\section{HASIL}

Validator ahli materi mikrobiologi adalah Dr. Dwi Wahyuni, M.Kes (Dosen Mikrobiologi pada Pendidikan Biologi Universitas Jember). Hasil validasi dari validator ahli materi mikrobiologi menunjukkan bahwa aspek 1 yakni materi ajar sudah mencakup morfologi virus, bakteri, fungi, protozoa, dan algae memiliki kriteria kevalidan sebesar $50 \%$ yang berarti cukup valid (revisi), aspek 2 yakni uraian materi ajar dapat membantu mahasiswa dalam memahami morfologi mikroorganisme memiliki kriteria kevalidan 
sebesar 75\% yang berarti valid (tidak revisi), dan aspek 3 yakni lembar kegiatan praktikum dapat membantu mahasiswa dalam memahami morfologi bakteri adalah sebesar 50\% yang berarti cukup valid (revisi). Hasil penilaian oleh validator akan dilakukan revisi atau perbaikan sesuai dengan saran dari validator da- lam hal ini pada aspek 1 akan ditambahkan hasil penelitian terbaru yang berkaitan dengan morfologi mikroorganisme sedangkan pada aspek 3 akan diperbaiki petunjuk praktikum dalam pengamatan morfologi mikroorganisme sehingga hasil revisi yang dilakukan akan menyempurnakan materi yang dikembangkan.

Tabel 1. Tahapan model pengembangan Thiagarajan (4D)

\begin{tabular}{|c|c|c|}
\hline No & $\begin{array}{c}\text { Model Pengembangan } \\
\text { Thiagarajan 4D } \\
\end{array}$ & Keterangan \\
\hline \multirow[t]{4}{*}{1} & \multirow[t]{4}{*}{ Tahap pendefinisian (Define) } & $\begin{array}{l}\text { Analisis ujung depan, kegiatan ini dapat dilakukan dengan } \\
\text { wawancara pada dosen pengampu matakuliah dan } \\
\text { menganalisis SAP terkait dengan masalah-masalah pada } \\
\text { matakuliah mikrobiologi. }\end{array}$ \\
\hline & & $\begin{array}{l}\text { Analisis tugas dan konsep, kegiatan ini dapat dilakukan dengan } \\
\text { menganalisis kompetensi dasar matakuliah mikrobiologi } \\
\text { untuk mengembangkan materi ajar. }\end{array}$ \\
\hline & & $\begin{array}{l}\text { Analisis tujuan, kegiatan ini dapat dilakukan dengan meng- } \\
\text { identifikasi kedalam/keluasan materi yang harus dikuasai } \\
\text { oleh mahasiswa yang menempuh matakuliah mikrobiologi. }\end{array}$ \\
\hline & & $\begin{array}{l}\text { Identifikasi sumber pustaka, kegiatan ini dapat dilakukan } \\
\text { dengan menganalisis kekurangan-kekurangan dari sumber } \\
\text { pustaka yang digunakan dalam perkuliahan mikrobiologi }\end{array}$ \\
\hline \multirow[t]{2}{*}{2} & \multirow[t]{2}{*}{ Tahap perancangan (Design) } & $\begin{array}{l}\text { Pemilihan media, menentukan alternatif pemilihan media } \\
\text { untuk mengatasi permasalahan pada analisis ujung depan } \\
\text { dan media yang dipilih adalah materi ajar. }\end{array}$ \\
\hline & & $\begin{array}{l}\text { Pemilihan format, dilakukan dengan penyusunan draft materi } \\
\text { ajar }\end{array}$ \\
\hline \multirow[t]{3}{*}{3} & \multirow[t]{3}{*}{$\begin{array}{l}\text { Tahap pengembangan } \\
\text { (Develop) }\end{array}$} & $\begin{array}{l}\text { Validasi, dilakukan kegiatan penilaian terhadapat materi } \\
\text { ajar yang dikembangkan. Validator yang terlibat antara } \\
\text { lain; validator ahli materi mikrobiologi, validator ahli media } \\
\text { pembelajaran, dan validator pengguna (praktisi) serta } \\
\text { tanggapan hasil uji coba skala kecil. }\end{array}$ \\
\hline & & $\begin{array}{l}\text { Revisi, suatu proses penyempurnaan materi ajar setelah } \\
\text { memperoleh masukan dari kegiatan validasi dan uji coba. }\end{array}$ \\
\hline & & $\begin{array}{l}\text { Uji skala kecil, merupakan kegiatan uji keterbacaan dan } \\
\text { kelayakan materi ajar oleh mahasiswa yang telah menempuh } \\
\text { matakuliah mikrobiologi. }\end{array}$ \\
\hline 4 & $\begin{array}{l}\text { Tahap penyebarluasan } \\
\text { (Disseminate) }\end{array}$ & Pada penelitian ini tidak dilakukan. \\
\hline
\end{tabular}

Tabel 2. Kriteria Kevalidan Data Angket Penilaian oleh Para Validator dan Hasil Uji Coba Skala Kecil Ditinjau dari Hasil Prosentase

\begin{tabular}{|c|c|}
\hline Skala nilai (100\%) & Keterangan \\
\hline $81-100$ & Sangat valid (tidak revisi) \\
$61-80$ & Valid (tidak revisi) \\
$41-60$ & Cukup valid (revisi) \\
$21-40$ & Kurang valid (revisi) \\
$0-20$ & Sangat tidak valid (revisi) \\
\hline
\end{tabular}

(Sumber: Suwastono, 2011) 
Validator ahli media pembelajaran adalah Dr. Drs. A .J. E. Toenlioe, M.Pd (Dosen Fakultas Ilmu Pendidikan Universitas Negeri Malang). Hasil penilaian oleh validator ahli media mendapatkan nilai $100 \%$ untuk ukuran buku yang berarti sangat valid, 75\% untuk desain buku sampul yang berarti valid, $100 \%$ untuk tipografi sampul buku yang berarti sangat valid, 75\% untuk ilustrasi buku yang berarti valid, 100\% untuk desain isi buku yang berarti sangat valid, $100 \%$ untuk tipografi isi buku yang berarti sangat valid. Berdasarkan hasil penilaian oleh ahli media diperoleh kriteria valid sehingga layak untuk dipergunakan.

Validator pengguna (praktisi) adalah Purwaning Budi Lestari, S.Pd, M.Pd (Dosen Mikrobiologi pada Pendidikan Biologi IKIP Budi Utomo Malang). Hasil penialian oleh praktisi diperoleh nilai $100 \%$ untuk kesesuaian waktu dengan penggunaan materi, 100\% untuk materi yang dikembangkan telah sesuai dengan indikator, $100 \%$ untuk pemanfaatan dan ketertarikan mahasiswa terhadap materi yang dikembangkan, 100\% untuk materi yang dapat membantu mahasiswa dalam memahami materi, 100\% untuk aspek materi yang mampu mengaktifkan mahasiswa serta mampu membangun pengetahuannya sendiri. Berdasarkan hasil penialian oleh praktisi diperoleh kriteria sangat valid sehingga tidak dilakukan revisi.

Tanggapan mahasiswa dilakukan setelah revisi dari hasil penialian oleh validator ahli materi, media, dan praktisi. Hasil tanggapan oleh mahasiswa diperoleh beberapa penilaian antara lain nilai 98,8\% untuk kejelasan identitas materi, 92,5\% untuk kejelasan bahasa pada materi, 92,5\% untuk keruntutan materi, 91,3\% untuk pemahaman soal evaluasi pada materi, 96,3\% untuk bahasan yang digunakan dalam materi, $82,5 \%$ untuk kejelasan petunjuk praktikum pada materi yang dikembangkan. Berdasarkan hasil penilaian oleh mahasiswa maka kriteria yang diperoleh adalah sangat valid, sehingga materi yang dikembangkan dinyatakan valid dan layak untuk digunakan.

\section{PEMBAHASAN}

Berdasarkan hasil penelitian menunjukkan bahwa materi ajar pada pokok bahasan morfologi mikrobiologi berbasis saintific approach dinyatakan layak. Materi ajar dikembangkan dengan menggunakan model pengembangan bahan ajar Thiagarajan (4D) memuat; morfologi mikroorganisme dan lembar kegiatan praktikum dengan topik pengamatan morfologi bakteri. Pernyataan di atas sesuai dengan pendapat Lestari (2013) bahwa penyusunan materi ajar harus memaparkan materi, lembar kegiatan praktikum dan umpan balik untuk mengukur penguasaan konsep peserta didik. Sjamsuddin (2004) menambahkan bahwa materi ajar adalah sumber belajar dalam bentuk media cetak yang sengaja dibuat untuk mempermudah proses pembelajaran. Parulian dan Situmorang (2013) juga menambahkan bahwa materi ajar yang dikembangkan harus mengandung inovasi materi dan ilustrasi gambar, serta kegiatan yang mampu meningkatkan pemahaman peserta didik misalkan melalui kegiatan praktikum.

Materi ajar mikroiologi ini dikembangkan berdasarkan kompetensi dasar yang ditetapkan, sehingga materi-materi dan kegiatan praktikum yang termuat dalam materi ajar sesuai dengan pencapaian tujuan yang ditetapkan. Pernyataan di atas sesui dengan pendapat Hasibuan (2014) yang menjelaskan bahwa materi ajar yang dikembangkan harus mampu memacu proses pembelajaran yang berjalan sesuai dengan tujuan pembelajaran yang telah ada.

Karakter scientific approach pada materi mikrobiologi ini dimunculkan pada kegiatan praktikum, yang mana dalam kegiatan itu terdapat 5M yakni; (1) mengamati (observing), (2) menanya (questioning), (3) menalar (associating), (4) mencoba (experimenting), dan (5) membuat jejaring (networking). Akan tetapi, pelaksaan dari 5M dalam materi ajar tidak runtut. Pernyataan di atas sesuai dengan penjelasan Kemendikbud (2013) bahwa 5M dalam pelaksanaannya bisa dimulai dari tahapan manapun. Ryberg (2010) menambahkan scientific approach adalah salah satu pendekatan yang mampu menginspirasi atau mendasari perumusan metode mengajar dengan menerapkan karakteristik yang ilmiah, yang mana pada materi ajar yang dikembangkan dimunculkan padakegiatan praktikum, sehingga dapat menciptkan peserta didik yang produktif, kreatif, dan inovatif melalui penguatan sikap, keterampilan, dan pengetahuan yang terintegrasi.

Tujuan dimunculkannya scientific approach pada materi ajar yang dikembangkan adalah memacu para mahasiswa agar karakter inovatornya berkembang melalui kegiatan 5M. Hal ini sesuai dengan pendapat Dyer, et al (2009) bahwa pendekatan saintifik (scientific approach) ini diadaptasi dari konsep Inovator's DNA yang menyatakan seseorang memiliki karakteristik 
sebagai inovator jika memiliki kemampuan untukmengasosiasikansatu peristiwa dengan peristiwa lainnya (associating), bertanya tentang halhal yang belum pernah ada atau belum pernah dilakukan (questioning), melakukan pengamatan lingkungan sekelilingnya (observing), membuat jejaring untuk memperoleh hasil yang lebih baik (networking) dan melakukan eksperimen untuk mencapai inovasi (experimenting).

Kelebihan materi ajar mikrobiologi pada pokok bahasan morfologi mikroorganisme berbasis scientific approach adalah: (1) materi ajar disusun berdasarkan permasalah dalam proses perkuliahan mikrobiologi, (2) materi ajar ini dikembangkan berdasarkan kompetensi dasar yang harus dikuasai oleh mahasiswa yang sedang menempuh matakuliah mikrobiologi, (3) materi ajar ini memiliki keunikan yakni bersudut pandang pendekatan sainstifik (scientific approach) sehingga dapat memacu para masiswa untuk berinovasi sesuai karakteristik masingmasing mahasiswa, dan (4) materi ajar ini dinyatakan layak karena memenuhi kriteria kelayakan sehinga dapat digunakan dalam proses perkuliahan mikrobiologi.

\section{KESIMPULAN DAN SARAN}

Materi ajar pada pokok bahasan morfologi mikroorganisme berbasis saintific approach yang dikembangkan oleh peneliti dinyatakan valid dan layak. Valid dan layak dari segi materi maupun media pembelajaran yang diperoleh dari penilaian validator ahli materi mikrobiologi dan ahli media pembelajaran. Kevalidan dan kelayakan dari materi ajar yang dikembangkan oleh peneliti juga dibuktikan oleh hasil penilaian dari pengguna (praktisi) dan mahasiswa sebagai pengguna materi ajar, yang menyatakan valid dan layak. Sehingga materi ajar pada pokok bahasan morfologi mikroorganisme berbasis saintific approach dapat digunakan dalam perkuliahan mikrobiologi.

Saran yang diperlukan untuk peneliti sejenis adalah diharapkan dapat mengembangkan materi ajar pada pokok bahasan yang lainnya untuk kelengkapan materi pada matakuliah mikrobiologi secara keseluruhan.

\section{DAFTAR RUJUKAN}

BNSP. 2010. Paradigma Pendidikan Nasional Abad XXI. Badan Standar Nasional Pendidikan Versi 1.0

Dyer, J. H.; Gregersen, H. B., and Christensen, C. M (2009) The innovator's DNA, Harvard Business Review, December 2009, pp. 1-10.

Hasibuan, M.P. 2014. Pengembangan Buku Ajar Kimia SMA/MA Kelas XI Semester I Berdasarkan Kurikulum 2013 dalam Upaya Meningkatkan Hasil Belajar dan Menumbuhkembangkan Karakter Siswa, Tesis, Program Pasca Sarjana. Universitas Negeri Medan. Medan.

Murti, K.. 2002. Pendidikan Abad 21 dan Implementasinya pada Pembelajaran di Sekolah Menengah Kejuruan (SMK) untuk Paket Keahlian Desain Interior. Artikel Kurikulum 2013 SMK.

Parulian, H.G., dan Situmorang, M. 2014. Inovasi Pembelajaran Di dalam Buku Ajar Kimia SMA Untuk Meningkatkan Hasil Belajar Siswa, Jurnal Penelitian Bidang Pendidikan, 19 (2): 67-78.

Ryberg, T. 2010. Implementation of Scientific Approach for Activities Laboratory. Journal paedagogy. Vol 32 (45-68).

SAP Matakuliah Mikrobiologi Program Studi Pendidikan Biologi, FPIEK, IKIP Budi Utomo Malang. Tahun ajaran 2014/ 2015.

Sugiyono. 1999. Metode Penelitian Bisnis. Bandung: Alfabeta.

Suwastono, A. 2011. Pengembangan Pembelajaran E-LerningBerbasisMoodlepadaMatakuliah Pengindraan Jauh S1, Jurusan Geografi, Universitas Negeri Malang. Tesis tidak diterpitkan. Malang: PPs UM.

Thiagarajan. 1974. Instructional Development for Training Teachers of Exceptional Children. University of Minnesota. 
128 | Trio Ageng Prayitno, Model Pengembangan Materi Ajar ... 